\title{
PREVALENCE OF INJURIES AMONG WASTE PICKERS. A CASE STUDY IN NIGERIA
}

\author{
Ahmed Fate Ali ${ }^{1, *}$ and Farouk Idi Yusuf ${ }^{2}$ \\ ${ }^{1}$ Department of Environmental Management, Bayero University Kano, Gwarzo Road, P.M.B. 3011, Kano, Nigeria \\ ${ }^{2}$ Department of Geography, Federal College of Education Yola, P.M.B 2042, Yola, Adamawa State, Nigeria
}

Article Info:
Received:
24 February 2020
Revised:
19 November 2021
Accepted:
19 November 2021
Available online:
19 December 2021
Keywords:
Bauchi
Health
Safety
Injuries
Waste pickers

\section{INTRODUCTION}

Solid waste management (SWM) has become a serious problem in most cities of the world, and a topic of growing concern especially in Low-Income countries, (Lavagnolo and Grossule, 2018; Ali et al., 2017). In the view of United Nations Sustainable Development Goals (SDGs) 12, the global goals will be met effectively only once waste management is recognized as a powerful driver of sustainable development (SDG, 2019). This can be realized through the substantial reduction of waste generation, prevention, recycling and reuse (Nurfaiza et al., 2019), considering some fundamental factors which underpin the operation and the enhancement of SWM in developing countries (Mukhtar et al., 2018).

Several authors encouraged the act of waste picking as part of waste management and resource recovery to ensure environmental sustainability (Gutberlet et al., 2020; Nzeadibe, 2019; Steuer et al., 2018; Nabegu et al., 2017; Adama, 2012) as this helps meet the growing demands of raw materials and the reduction of significant amounts of waste. For instance, Ogwueleka (2009) revealed that $40 \%$ of artisans and small-scale industries in Onitsha, Nigeria, receive $48 \%$ of their raw materials from waste pickers. It also provides job opportunities for many people through the recovery of recyclable materials across the Low-Income Countries (Bonini-Rocha, 2021). For example, about $86 \%$ of waste pickers generate more than $\$ 20,000$ per month in Warri, Nigeria, which equates to more than the minimum wage scale in the country (Irabor and Oghenekohwiroro, 2017).

According to Lambu (2016), the process of waste picking involves the collection, purchase, and recovery of materials for economic benefits. Reno (2019) stated that waste picking is portrayed as something done out of necessity and that the people doing it suffer from abject poverty. These informal workers represent a significant proportion of the world's working poor, with over 15 million people undertaking such work, primarily in Low-Income countries (Medina, 2009) and about 1 million across Nigerian cities (Nzeadibe, 2019). Waste picking is a physically demanding work, as it involves carrying heavy loads of recyclable materials and walking for hours without adequate rest (Mathema et al., 2017). This could lead to the development of musculoskeletal problems, such as back, shoulder and neck pain, among others (Singh and Chokhandre, 2015). As a result of the environment in which they work, waste pick- 
ers are also prone to other physical injuries, including cuts from sharp objects, such as pieces of glass, razor blades, scrap metal and pricks from piercing items like needles and nails. This eventually becomes the entry points for infection and exposure to bacteria (Yusuf et al., 2021).

Despite their vulunerablility to injury, a number of studies narrated how waste pickers attributed injuries and diseases to God's will and supernatural phenomena, rather than to work-related causes; for example Nzeadibe et al. (2012) reported that most of the waste pickers in Aba do not believe that the health and safety problems they face are related to their occupation, but rather they are related to the influence of witchcraft from their communities. Chimere et al. (2017) found a similar result across Ibadan, Lagos, and also Aba (however, on e-waste informal workers).

Chukwunonye et al. (2009) revealed that the waste pickers in Nigeria are not aware of the dangers of their occupation and are concerned only with the economic benefits of the occupation; Uthman et al. (2017) confirmed a similar finding in Illorin. The consequence of such negative beliefs makes it difficult for waste pickers to comply with health and safety rules. For example, some waste pickers often walk in a heap of waste without shoes and use their bare hands to search for recyclables through clinical and other hazardous wastes without gloves. Moreover, their health status must be considered a public health issue as well, as they could be potential spreaders of communicable diseases to the populace (Chukwunonye et al. 2009).

It is of great concern to know that very little research has been conducted in the northern part of Nigeria in regard to waste picking, despite the presence of prejudice socio-economic and cultural conditions in the region which lead to the growth of the informal sector (Adama, 2014). The few available research were, however, focused primarily on the socio-economic wellbeing of waste pickers, e.g., Nzeadibe (2019), Lambu (2016); Adama (2014) and Nzeadibe et al. (2012 \& 2013), and the risk-awareness of waste scavengers, e.g., Uthman et al. (2017). Eventhough, Ohajinwa et al., 2018 studied prevalence and injury patterns among electronic waste workers in Nigeria, this study has concentrated, largely, on waste pickers. . The study also examined the various methods used by the waste pickers in treating injuries, with the view of proffering solutions regarding their health and safety, as well as halting or minimizing the possible spread of infectious diseases to the general public as essential components of sustainable development goals (SDG 3). Taking into consideration that most of those waste pickers are Internally Displaced Persons (IDPs) and Almajiri children, who rely considerably on waste picking as a means of livelihood. Almajiri refers to under-aged children that leave their hometowns and travel to other towns or cities in the pursuit of Islamic education particularly in northern Nigeria and some parts of West Africa (Yusuf et al., 2021).

The study was conducted in Bauchi city, in the North-eastern region of Nigeria. The city, which has a population of almost 800,000 inh., was chosen because it serves as a refugee safe zone for the residents of the neighboring states of Borno, Yobe, and Adamawa due to the recent Boko Haram insurgency and the security insta- bility of Plateau state. This led to increased dependency on informal activities (including waste picking). Another important factor is the high number of Almajiri children in the city. Similarly, the state has about 1,080,150 out-of-school children, which is the second highest in Nigeria after Kano State (UNICEF, 2019).

The problem of waste management systems in Bauchi city is similar to that seen in other cities, e.g., Chukwunonye \& Clive (2012) in Abuja; Nzeadibe \& Anyadike (2012) in Aba; Kofoworola (2007) in Lagos; and Maigari (2014) in Kano. The system reflects low levels of public awareness of, and poor institutional/regulatory framework for, sustainable solid waste management (Chukwunonye \& Clive, 2012). According to Bogoro et al. (2013), Bauchi city has 89 recognized dumpsites that are managed by Bauchi State Environmental Protection Agency (BASEPA). Some of the dumpsites designated by the agency include a Railway playground, a Games village playground, Kofar Idi, Karofi, and Yelwantudu, among others. Surprisingly, illegal dumpsites almost tripled the recognized dumpsites by the BASEPA, which has recorded 205 sites around the city streets, drainages, and uncompleted buildings. Nonetheless, both the recognized and illegal dumpsites serve as source of recyclables to the waste pickers.

\section{MATERIALS AND METHODS}

Mixed-method approach was adopted for this study due to the flexibility needed to accommodate the whole nature of the research objectives. This approach uses a mix of quantitative and qualitative data in the collection and analysis stages of a single study (Croswell and Plano, 2011). The results of the qualitative data support the quantitative data and reflect the voice of the waste pickers and their masters (i.e., middlemen) where necessary.

\subsection{Sampling procedure}

Researchers find it difficult to reach waste-pickers, as they cannot be pinned down to a specific dumpsite at a specific time. The best place to find waste pickers is where they sell the recyclables they have collected (Schenck and Blaauw, 2011). This reason, coupled with a fear of collecting data more than once from a particular group or individual waste pickers in a dumpsite, warranted the need to reach the respondents (waste pickers) in the middlemen shops (i.e., where the waste pickers sell the collected waste items). Middlemen are agents who sit next to the waste pickers in the recycling chain (Adama, 2014). Middleman operate as buyers who store and might process waste recyclables before transferring them to final recycling (Steuer et al., 2018).

Using stratified and simple random sampling, 88 middlemen shops were selected from 121 registered middlemen from their union. In order to ensure proper representation of the population of the study, the middlemen shops were selected based on the type of recyclables they purchase; i.e., from those who buy plastic bottles ("robobi"), rubber ("danko"), aluminium and metal ("dalma da karfe") bottles and cables ("kwalba da waya"), and carton boxes ("kwali"). Three hundred and twenty-two waste pickers were sampled 
across the 80 middlemen shops; the selection was based on the numbers of waste pickers per middlemen shop. The sampled locations were visited mostly between $4 \mathrm{pm}$ and $6 \mathrm{pm}$, when the waste pickers typically arrive at the Middlemen shops to sell their recyclable items. Questionnaires were used to capture data from the waste pickers, and interviews were conducted in the local language (Hausa) to complement the responses. The interview comprised two sections: one for the waste pickers, and one for the middlemen. This helped obtain sufficient information required for the study, and also elicited the co-operation of the middlemen in the sense that they felt involved and comfortable with the data gatherings. Field observation was also underken where pictures of injuries were taken, alongside other vital information related to waste picking activities. Subsequently, GPS was used to capture the coordinates of the 80 sampled middlemen shops' locations. Figure 1 illustrates the locations of 77 out of the 80 sampled middlemen shops using Gamin GPS. Most of the middlemen shops are concentrated around Muda-lawan market, IBB Square, Sabon-kasuwa, Wunti, Makera, and Gwallaga. Although there are few outlying areas that have more than four middlemen shops, such as Gombe Road, Tirwun, Yelwa, and Inkil. Based on the survey, the concentration of the middlemen shops correlates with densely populated areas and proximity to markets. But nevertheless, the use of tools such as GPS and GIS could be important for mapping and tracking informal waste management activities and related impacts (Villa et al., 2020; Golder and Alamgir, 2018). The survey was conducted from December 2019 to March 2020. Four men team participated in the survey. Ethical approval was granted by Bauchi state Government before the commencement of the research work.

\section{RESULTS AND DISCUSSION}

\subsection{The socio-demographic characteristics of the respondents}

Table 1 indicates that all the respondents were male. This is because scavenging activity in the northern part of Nigeria is a male-dominated occupation (Nzeadibe, 2009). This factor could be attributed to the culture of the study area, which restricts women from participating in some occupations, especially in the informal sector. The age structure in the study shows that more than half of the respondents (52\%) were 18 years and below; $38 \%$ are between 19 and 29 years old; $9 \%$ are between 30 to 39 while the remaining $1 \%$ are aged 40 years and above. Obviously, children and teenagers formed the majority of the waste picking occupation. Educationally, 35\% of the waste pickers did not attend any formal education; while $41 \%$ attended primary school, and $24 \%$ attended secondary school. According to the result none of the respondents is educated beyond secondary school. Moreover, about $28 \%$ of the waste pickers engaged in the occupation for 1 year and below; while those in the occupation for $2-5$ years stand at $38 \%$, and between 6-10 represent $19 \%$, while those that have worked for 11 years above are $15 \%$. About 1 in 5 of the respondents worked in dry season only, while the remaining almost $80 \%$ worked all year round.

\subsection{Work-related injuries among waste pickers}

The results reveal (Table 2) that 246 out of 313 respondents reported cases of injury, while the remaining 66 claimed never to have sustained any injury. A total of one thousand four hundred and seventy-four (1474) multiple injuries had been reported amongst the waste pickers since they engaged in the job. Among the injured respondents, about $37.8 \%$ suffered from cuts by sharp objects, which include metal, glass/broken bottles and razor blades, followed by $23.7 \%$ cases of musculoskeletal injury, which includes joint, shoulder, neck and back pains. Irritations/ rashes ranked as the third most reported case, which accounts for $14 \%$ of the total. $13.5 \%$ suffered from animal/insect bites, while $10.6 \%$ reported being pierced or punctured by needles and nails, whereas $8.3 \%$ suffered from waste heap fire burns.

According to the result, cuts represent the highest score. This may be due to the presence of clinical and industrial sharp waste items in the dumpsites and could also be linked to the poor waste management in the city by the responsible government agency (BASEPA). The agency does not enforce a policy for the segregation of industrial and medical wastes from domestic waste, thus further exposing waste pickers to a wide array of risks. Moreover, according to Bogoro et al. (2012), BASEPA is responsible for managing waste at city level. The resultant poor management also causes perforation/piercing of the feet and hands of the waste pickers by pandemic needles, nails, animal bones, sharp metals, among others, when searching for recyclables in heaps of waste. A similar assertion was made by Rushton (2003), who stated that the risks associated with waste remain prevalent in Low-Income nations because the regulatory framework and enforcement system to separate hazardous wastes are largely absent.

Based on the result, musculoskeletal injury ranks second, which could be due to lifting heavy loads, and alternate bending and trekking. This is in accordance with Jerie's (2016) findings, which revealed that the activity of solid waste pickers exposed them to considerable risk of developing ergonomic disorders, such as lower back pain and neck pain, and may also affect their shoulders and arms. Similarly, Leton and Nweke (2013) reported that bending and carrying heavy loads of scavenged items caused backache, pains in the arms and legs, and joint stiffness. Burns to the feet and hands of waste pickers was found to be the least prevalent injury (13.6\%). This may be due to fires set by residents living around the dumpsites for volume reduction, which further endangers waste pickers while searching for recyclables.

Despite the reported cases of injury featured in the study, some waste pickers claimed that they had never experienced any injury or even that they were naturally made immune by God. For example, one waste picker narrated that "many people think that we are getting closer to our grave by doing this job without knowing that God protects us more than anyone." The responses to religious faith among the waste pickers comes back on a regular basis, as some believe that Personal Protective Equipment (PPE) will never protect them from sustaining injuries or contract- 


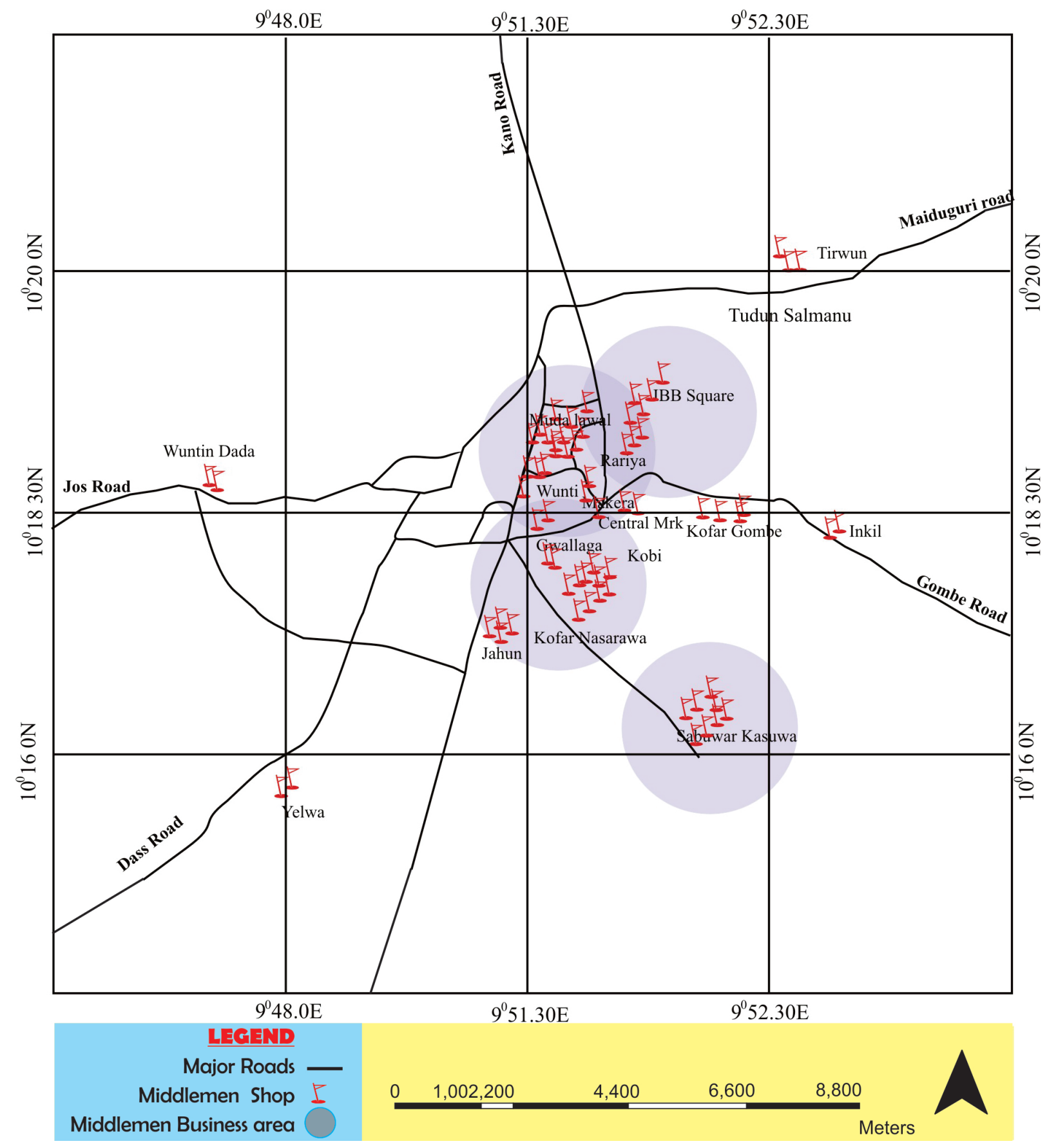

FIGURE 1: Locations of Middlemen shops.

ing diseases. This is similar to the findings of Nzeadibe et al.'s (2012) in Aba. The waste pickers defend the fact that no one can run away from injuries even when they wear protective clothes. They seem to accept their fate as a decision of God, and rely on Him for protection.

\subsection{Influence of socio-demographic characteristics on work related injuries}

It is important to note that age is an important parameter associated with the prevalence of injuries among the waste pickers. However, a chi-square test was performed to demonstrate the association between occupational characteristics and the occurrence of work-related injuries. The Chi-square result (Table 3 ) shows a significant relation between age $(p=0.000)$, educational qualification $(p=0.011)$ and working experiences $(p=0.005)$ with the prevalence of injuries. Meanwhile, no relation was found between working hours $(p=0.098)$, working days $(p=0.078)$ and working season $(p=0.059)$ with the prevalence of injuries. Based on the result, one can conclude that injuries are more prevalent among the lower age group than the higher age group and are also higher among non-formal literate waste pickers than those who attended formal education. This is apparent as child waste pickers reported more cas- 
TABLE 1: Waste pickers' socio-demographic and occupational characteristics.

\begin{tabular}{|c|c|c|}
\hline Characteristic & Frequency & $\%$ \\
\hline \multicolumn{3}{|c|}{ Sex } \\
\hline Male & 313 & 100 \\
\hline Female & 00 & 00 \\
\hline Total & 313 & 100 \\
\hline \multicolumn{3}{|c|}{ Age } \\
\hline 18 and below & 161 & 52 \\
\hline $19-29$ & 121 & 38 \\
\hline $30-39$ & 26 & 09 \\
\hline 40 and above & 04 & 01 \\
\hline Total & 313 & 100 \\
\hline \multicolumn{3}{|c|}{ Educational Level } \\
\hline None & 111 & 35 \\
\hline Primary & 127 & 41 \\
\hline Secondary & 74 & 24 \\
\hline Tertiary & 00 & 00 \\
\hline Total & 313 & 100 \\
\hline \multicolumn{3}{|c|}{ Working Experience } \\
\hline 1year below & 86 & 28 \\
\hline 2-5years & 120 & 38 \\
\hline $6-10$ years & 60 & 19 \\
\hline 11 and above & 47 & 15 \\
\hline Total & 313 & 100 \\
\hline \multicolumn{3}{|c|}{ Working Season } \\
\hline All Seasons & 248 & 79 \\
\hline Dry season & 62 & 21 \\
\hline Rainy Season & 00 & 00 \\
\hline Total & 313 & 100 \\
\hline \multicolumn{3}{|c|}{ Working Hours } \\
\hline 1-3 Hours & 38 & 12 \\
\hline 4-7 Hours & 135 & 44 \\
\hline $8-10$ hours & 134 & 43 \\
\hline 11 and above Hours & 03 & 01 \\
\hline
\end{tabular}

es of injuries than adults. This goes along with) findings which revealed that the number of injuries decreased with the increase in age (Ivens et al., 1998).

Similarly, most Almajiri children and IDPs who did not attend formal school reported more incidents of injury than those who attended primary or secondary schools. Perhaps those who attended school are more aware of the potential risks of the occupation than those with non-formal school qualification. Subsequently, years of experience and working hours, days and seasons do not determine the high incidence of injury among the waste pickers.

\subsection{4. Methods of treating injury by the waste pi- ckers}

The study discovered only $17 \%$ of the waste pickers visit the clinic when injury occurs. Another $29 \%$ go to a
TABLE 2: Prevalence of Injuries among waste pickers.

\begin{tabular}{|c|c|c|c|}
\hline \multicolumn{2}{|l|}{ Injuries } & Frequency & \multirow{2}{*}{$\begin{array}{c}\% \\
18.67\end{array}$} \\
\hline Cuts & Sharp metal & 249 & \\
\hline & Broken-glass & 174 & 13.04 \\
\hline & Razor blade & 81 & 6.07 \\
\hline & Total & $\underline{504}$ & $\underline{\mathbf{3 7 . 7 8}}$ \\
\hline \multirow[t]{3}{*}{ Punch } & Clinical needle pierce & 93 & 6.97 \\
\hline & Nail puncture & 48 & 3.60 \\
\hline & Total & 141 & 10.57 \\
\hline \multirow[t]{3}{*}{ Burns } & Foot burns & 88 & 6.60 \\
\hline & Hand burns & 23 & 1.72 \\
\hline & Total & $\underline{111}$ & $\underline{8.32}$ \\
\hline \multirow{5}{*}{$\begin{array}{l}\text { Animal /Rodents } \\
\text { bites }\end{array}$} & Dog & 2 & 0.15 \\
\hline & Rat/Mice & 24 & 1.80 \\
\hline & Scorpion & 29 & 2.17 \\
\hline & Insect/flies & 144 & 9.7 \\
\hline & Total & 196 & 13.86 \\
\hline \multirow[t]{6}{*}{ Musculoskeletal } & Back pain & 45 & 3.37 \\
\hline & Neck pain & 48 & 3.60 \\
\hline & Chest pain & 31 & 2.32 \\
\hline & Shoulder pain & 108 & 8.10 \\
\hline & Joint pains & 84 & 6.30 \\
\hline & Total & $\underline{316}$ & $\underline{23.69}$ \\
\hline \multirow{6}{*}{$\begin{array}{l}\text { Irritations/ } \\
\text { rashes }\end{array}$} & Nasal irritation & 3 & 0.22 \\
\hline & Eye irritation & 9 & 0.67 \\
\hline & Skin irritation & 141 & 10.57 \\
\hline & Swelling limps & 43 & 3.22 \\
\hline & Total & $\underline{196}$ & $\underline{14.16}$ \\
\hline & Others & $\underline{11}$ & $\underline{0.82}$ \\
\hline \multicolumn{2}{|l|}{ Grand Total } & 1474 & $100 \%$ \\
\hline
\end{tabular}

nearby pharmacy for treatment, while the remaining $54 \%$ had their own methods of treatment, from the dumpsite (the point where injuries occur) to the healing stage. These methods (Table 4) include the use of procaine powder and herbal medicinal leaf; other mixtures sound unbelievable, for example, ash, sand, salt, grass fluid, hydraulic, kerosene, and car battery acid. All these are used by the waste pickers as healing remedies for their wounds and bruises.

During the interview session, when one of the middlemen was asked about the treatment of injuries, he affirmed that the waste pickers do not buy medicine with their money. Moreover, even if they were given money to go to the nearest chemist or clinic, they do not; instead, they spend the money. While the other middleman narrated that they save some money out of their earnings and take waste pickers to the clinic or chemist when injuries occur; if not, they will not pay for their treatment, because their health condition is not their concern.

The interviewer also asked, "Why can't you provide PPE to them to minimize injuries and save your money?" He responded: "It is not our responsibility, because we pay them 
TABLE 3: Summary of Chi-Square test for association of occupational characteristics and prevalence of injuries among waste pickers@0.05significance level.

\begin{tabular}{l|c:ccc}
\hline Variables & $\mathbf{X}^{2}$ & d.f & p value \\
\hline Age & 112.62 & 3 & 0.000 \\
\hline Educational qualification & 129.71 & 2 & 0.011 \\
\hline Working Experiences & 165.14 & 2 & 0.005 \\
\hline Working Hours & 417.81 & 2 & 0.098 \\
\hline Working Days & 561.02 & 1 & 0.076 \\
\hline Working Season & 688.13 & 2 & 0.059 \\
\hline
\end{tabular}

TABLE 4: Treatment remedies for wounds, pricks and bruise by waste pickers.

\begin{tabular}{l|c|c}
\hline Treatment remedy & NO. & $\%$ \\
\hline Procaine Powder & 36 & 22.5 \\
\hdashline Ash & 26 & 15.5 \\
\hline Sand & 11 & 6.5 \\
\hline Salt & 28 & 16.6 \\
\hline Grass Fluid & 12 & 7.1 \\
\hline Hydraulic & 11 & 6.5 \\
\hline Kerosene & 15 & 9.0 \\
\hdashline Car Battery Acid & 11 & 6.5 \\
\hline Herbal Medicinal Leaf & 12 & 7.1 \\
\hline Others & 06 & 3.6 \\
\hline Total & 168 & 100 \\
\hline
\end{tabular}

for their hard labor; besides, even if we provide some PPE to them, they sell it".

As a matter of fact, there is lack of support from some middlemen regarding the health and safety of waste pickers, despite benefitting more from the recycling chain (Nzeadibe, 2019), while most of the waste pickers confirmed the unaffordability of PPE due to their low earnings. This is why some people relate the low incomes of waste pickers directly to the low pay by middlemen (Adama, 2014), which has a direct correlation with poor health and safety compliance. Moreover, waste picking in northern Nigeria is considered among the worst forms of child labor (International Labor Organization [ILO], 2004). This contradicts with SDG 8, which aims to protect labor rights and promote safe and secure working environments for all workers.

A similar method of curing needle piercing or cuts from broken bottle was reported by a picker, who said that, at times, they came across a broken needle in an injection bottle while washing the bottles and sometimes, before they noticed it, the needle would perforate their hand. The interviewer asked him, "What first aid measure do you take immediately?" He replied: "The water in which we wash the bottles contains leftovers of different injection medicines; and once we soaked our hand inside the bucket of water for some seconds the bleeding stops and gradually heals."

Regarding musculoskeletal injury, $86 \%$ of the respondents use different types of balm as a remedy, such as Adabarakur, Aboniki, Confo, and Tiger. Similarly, most of the respondents use the same medicinal balm to cure skin rashes/irritations.

\section{CONCLUSIONS}

Waste pickers do not perceive injury at work as serious enough to worry about. Hence, they do not go to the clinic when injury occurs; instead, they drip salt, ash, sand, battery acid, among others, into the pricks or wounds. The use of such remedies may kill body cells and gradually cause tissue damage. Cuts and piercing are the entry points for infection or pathogens following exposure to bacteria and viruses, which eventually spread infectious diseases to the general public. Regular medical check-ups and immunization against tetanus and other viral infections should be provided by the government to prevent waste pickers from contracting diseases.

The middlemen should provide PPE to the waste pickers and monitor them to ensure its effective use. This will help realize the maximum safety compliance by the waste pickers and, thus, reduce the potential risks and hazards present in the waste picking activities. Moreover, periodic sensitization gatherings should be carried out in each middlemen shop on issues concerning health and safety for the both middlemen and the waste pickers regarding the importance of PPE utilization.

There is a need for BASEPA to proffer arrangements for waste segregation from the source, as well as designating disposal sites for clinical and other hazardous waste, in order to minimize the occurrence of injuries and other environmental problems. It was observed that the waste scavengers' union only exist at the top level (i.e., middlemen) in Bauchi city. Therefore, there is a need for the waste pickers to form a union in order to protect their labour rights and have a fair relationship with the Middlemen. By so doing, it will be easier to organize and educate the members of the union on health and safety issues. Moreover, Nigerian Labour Congress (NLC) and International Labour Organisation (ILO) should intervene to ensure the employer and employee rights are maintained by law, between Waste pickers and Middlemen.

\section{REFERENCES}

Adama, O., 2014. Marginalization and intergration within the informal economy: the case study waste pickers in Kaduna, Nigeria. Article in International Development Planning Review.36(2), 155-180. DOI: 10.3828/idpr.2014.11.

Adamu, Y., 2018. The economic of scavenging business in Mubi metropolitan area. International Journal of Research Granthaalayah, 6(7), 191-199. DOI: 10.5281/zenodo.1325862.

Ali A.F., Tanko A. I. \& Kovo A.S., 2017. Solid Waste Management Practice in a Less Developed Urban Setting. Journal of Environmental Studies. 2017;3(1): 4. https://www.avensonline.org/wp-content/ uploads/JES-2471-4879-03-0018.pdf

Ajayi, O.A. and Ibrahim, A. T. (2021) Harnessing the Potentials of Almajiri Cohorts for Entrepreneurship development. Revista Universitară de Sociologie. XVII (1), 45 - 50. University of Craiova, Romania. http://www.sociologiecraiova.ro/revista/wp-content/ uploads/2021/04/RUS-1_2021_ff-45-50.pdf

Babanyara, Y.Y. \& Bogoro, A.G., 2011. Evacuation of solid waste in residential areas of Bauchi city, Nigeria. Journal of Environmental Sciences and Resource Management. 3, 10-29. https://ssrn.com/ abstract $=2028796$ 
Bogoro, A. G., Mohammed, Y. A. \& Babanyara, Y. Y., 2013. Indiscriminate Solid Waste Dioposal in Bauchi: Causes and Impacts on the Communityand the Environment. Journal of Environment and Earth Science. 3(4). ISSN 2224-3216.

Bonini-rocha, A. C., Alves, R., Oliveira, C. De, Bashash, M., Machado, C., Resende, V., \& Cruvinel, N., 2021. Prevalence of musculoskeletal disorders and risk factors in recyclable material waste pickers from the dump of the structural city in Brasília, Brazil. Waste Management, 125, 98-102. https://doi.org/10.1016/j.wasman.2021.02.018

Chimere, M., Ohajinwa, P. M., Van, B., Martina, G., Vijver, I. \& Willie, J. M., 2017. Health Risks Awareness of Electronic Waste Workers in the Informal Sector in Nigeria. International journal of environment research for public health. 14, 911. DOI:10.3390/ijerph14080911.

Chukwunonye, E. \& Clive, L. R., 2012. Analysis of barriers and success factors affecting the adoption of sustainable management of municipal solid waste in Nigeria. Journal of Environmental Management 103 (2012) 9-14. DOI: 10.1016/j.jenvman.2012.02.027

Chukwunonye, E., Roberts, C. L., Phillips, P. S., Lawrence, O. M. \&Nzeadibe, T. C., 2009. Evaluation of Public Health Impacts of Waste Scavenging in Abuja Nigeria. Conference paper Retrieved from: https://www.researchgate.net/publication/235418470.

Croswell, J.W. \& Plano, C.V., 2011. Designing and conducting mixed methods research. $2^{\text {nd }}$ ed. Thousand Oaks: Sage Research method for quantitative and qualitative study: mixed method. https://www. worldcat.org/title/designing-and-conducting-mixed methods research/oclc/558676948> (cited 12.05.20)

Golder, S., \& Alamgir, M., 2018. Use of geographical information system for the evaluation of solid waste management practice in khulna city. Detritus, 4(December), 178-188. https://doi. org/10.31025/2611-4135/2018.13743

Gutberlet, J., Besen, G. R., \& Morais, L. P., 2020. Participatory solid waste governance and the role of social and solidarity economy: Experiences from São Paulo, Brazil. Detritus, 13, 167-180. https:// doi.org/10.31025/2611-4135/2020.14024

International Labor Organization., 2004. Addressing the exploitation of children in waste picking: A thematic evaluation on actions on child labor. Geneva: International Labor Organization. https://www. scribd.com/document/465574515/2004-eval-scavenging-en

Irabor, G. A. \& Oghenekohwiroro, E., 2017. Assessment of the activities of scavengers and their economic impacts in waste recovery in Warri metropolis, Delta State Nigeria. International Research Journal of Public and Environmental Health. 4, 22-29. https://doi. org/10.15739/irjpeh.17.003

Ivens, U., Lassen, J. H., Kaltoft, B. S. \& Skov, T., 1998. Injuries among domestic waste collectors. American Journal of Industrial Medicine. 4, 26-28. https://doi.org/10.1002/(SICI)10970274(199802)33:2<182::AID-AJIM10>3.0.CO;2-X

Jerie, S., 2016. Occupational Risks Associated with Solid Waste Management in the Informal Sector of Gweru, Zimbabwe. Journal of Environmental and Environmental Public Health. 2016:9024160. DOI: 10.1155/2016/9024160.

Kofoworola, O. F., 2007. Recovery \& Recycling Practices in Municipal Solid Waste Management in Lagos, Nigeria. Waste Management Journal. 27, 1139-1143. DOI: 10.1016/j.wasman.2006.05.006

Lambu, I. B., 2016. Waste or Wealth' the Cultural Crux Behind Scavenging in Urban Kano State, Nigeria. Pyrex Journal of Research in Environmental Studies 3 (3), 19-25.

Leton, T.G. \& Olujide O., 2004. Landfill operations in the Niger delta region of Nigeria. Engineering Geology. 73, 171-177. DOI: 10.1016/j. enggeo.2003.12.006.

Maigari, A. I., 2014. Environmental Education and Sanitation in Urban Centres of KanoRegion. Research on Humanities and Social Sciences. 4(12), 85-91. https://RHSS/article/viewFile/13615/14214

Nabegu, A. B., 2008. The Role of Refuse Management and Sanitation Board (REMASAB) In Solid Waste Management in Kano Metropolis. Maiduguri Journal of Arts and Social Sciences, 6(2) https://www.researchgate.net/publication/255719043_

Nabegu, A.B., Bappah, B.A., Akpu, B. \& Mustapha, A., 2016. Constraints to municipal solid waste management in Bauchi city, Nigeria. International Journal of Applied Research and Technology. 5, 142-153.

National Population Commission., 2016. Bauchi city population. https:// www.citypopulation.de/php/nigeria-admin.php?adm1id=NGA005 cited 14.06.20
Nzeadibe, T. C., 2009. Solid waste reforms and informal recycling in Enugu urban area, Nigeria. Habitat International, 33, 93-99. DOI: 10.1016/j.habitatint.2008.05.006

Nzeadibe, T. C., Raymond, N. C., Anyadike \& Roseline, F. N., 2012. A Mixed Methods Approach to Vulnerability and Quality of Life Assessment of Waste Picking in Urban Nigeria.Applied Research in Quality of Life Journal of the International Society for Quality-ofLife StudiesVol. 7 No. 4. DOI: 10.1007/s11482-012-9171.

Nzeadibe, T.C, Anyadike, R.N., 2012. Social participation in city governance and urban livelihoods: Constraints to the informal recycling economy in Aba, Nigeria. City, Culture and Society, 3(4),313-325. DOI: 10.1016/j.ccs.2012.10.001.

Nzeadibe, T.C. \& Adama, O., 2013. Improved recycling performance: policy options for Nigerian cities. Policy Notes, 2013/2, pp.1-4. Uppsala, Sweden: The Nordic Africa Institute. http://nai.divaportal. org/smash/get/diva2:653251/FULLTEXT01.pdf

Nzedebe, T.C. \& Adama, O., 2015. Ingrained Inequalities? Deconstructing Gendered Spaces in the Informal Waste Economy of Nigerian Cities. Springer Science+Business Media Dordrecht. DOI 10.1007/ s12132-014-9246-0.

Nzedebe, T.C., Ambrose, O. I., Peter, O.M., Precious, C.O. \& Eberechu$\mathrm{ku}$, J.E., 2018. Children, waste and wellbeing: A critical analysis of socio-enviromental justice in almajirai solid wastes management in northern Nigerian cities. Article in African population studies Vol. $\quad 32$ No. 2 (supp 2). DOI: 10.11564/32-2-1191.

Nzeadibe, T. C., 2019. Value reclamation by municipal solid waste pickers and scrap dealers in Nigerian cities. Paper presentation at school of public health, room 1g, university of Western Cape, South Africa. DOI: 10.13140/RG.2.2.31232.69127

NorFaiza, M.T., Noor, A. H. \& Yusof, M. Z., 2019. Health Care Waste Management and Sustainable Development Goals in Malaysia. Journal of Wastes and Biomass Management (JWBM) 1(1) 18-20. http://doi.org/10.26480/jwbm.01.2019.18.20.

Ogwueleka, T.C., 2009. Municipal solid waste characteristics and management in Nigeria. Iranian Journal of Environmental Health Sci Eng. 6, 173-180. http://www.bioline.org.br/pdf?se09026

Ohajinwa, C. M., Bodegom, P. M. Van, Vijver, M. G., Olumide, A. O., Osibanjo, O., \& Peijnenburg, W. J. G. M., 2018. Prevalence and injury patterns among electronic waste workers in the informal sector in Nigeria. Injury Prevention; 24: 185-192. https://doi.org/10.1136/ injuryprev-2016-042265

Reno, J., 2009. Your trash is someone's treasure. Journal of Material Culture. 14, 29-46. https://doi.org/10.1177/1359183508100007.

Rushton, L., 2003. Health hazards and waste management. British $\mathrm{Me}$ dical Bulletin 2003; 68: 183197 British Medical Bulletin, Vol. 68 The British Council 2003; all rights reserved DOI: 10.1093/bmb/ Idg034. 68, 183-97.

Schenck, C. J. \& Blaauw P.F., 2011. Living on what others throw away: An exploration of the socioeconomic circumstances of people selling recyclable waste. The Social Work Practitioner Researcher. 23, 135-153. https://repository.uwc.ac.za/ xmlui/bitstream/handle/10566/770/SchenckSocioeconomic 01.pdf?sequence\&isAllowed =y

Singh, S. \& Chokhandre, P., 2015. Assessing the impact of waste picking on musculoskeletal disorders among waste pickers in Mumbai, India: a cross-sectional study. BMJ Open 2015; 5:e008474. doi:10.1136/bmjopen-2015- 008474.

Steuer, B., Ramusch, R., \& Salhofer, S., 2018. Is there a future for the informal recycling sector in urban China? Detritus, Volume 04 - December 2018. https://doi.org/10.31025/2611-4135/2018.13725.

Sustainable Development Goals., 2019. Report of the SecretaryGeneral, Special edition: progress towards the Sustainable Development Goals. https://wasteaid.org/waste-sustainable development-goals/

Uthman, A.Y., Imam-Fulani, O. A., Uthman, H. A., Ameen, B. F. Rotimi, A., Ahmed, H. K.,Oloyede, A. G. \& Salaudeen, O. M., 2017. Knowledge and experience of work related hazards and Utilization of Safety Practices among Solid Waste scavengers in Ilorin metropolis, Kwara State, Nigeria. Tropical Journal of Health Science. 24 (4) 1117-4153. https://www.ajol.info/index.php/tjhc/article/ view/164034

United Nations International Children's Emergency Fund (UNICEF), 2019. Addressing Out-of-school Children Challenge in Bauchi state. https://www.thisdaylive.com/index.php/2019/08/15/unicefbauchi-collaborate-to addressout-of-school-children-challenge/ (cited 09.06.20) 
Villa, F., Arcidiacono, A., Causone, F., Masera, G., Tadi, M., \& Grosso, M., 2020. Entering rocinha: A gis approach for the improvement of solid waste management in a slum in Rio de Janeiro (Brazil). Detritus, 9(March), 221-231. https://doi.org/10.31025/2611$4135 / 2020.13900$

Yusuf, F. I., Ali, A. F. \& Buba, L. F., 2021. Awareness of Occupational Hazards and Use of Protective Equipment among Waste Pickers in Bauchi City North-eastern Nigeria. Proceedings of the 2021 Annual Conference of Environmental Management Association of Nigeria. Kano, Nigeria. 2021; 447-460. 